\title{
Pengetahuan dan Sikap Ibu terhadap Pemberian ASI Eksklusif di Wilayah Kerja Puskesmas Simpang Kawat
}

\author{
Nurbaiti \\ Program Studi D III Kebidanan, STIKes Baiturrahim, Jambi, Indonesia \\ Email:nbaiti812@gmail.com
}

Submitted : 18/12/2020

Accepted: 10/09/2021

Published: 15/09/2021

\begin{abstract}
Breast milk contains colostrum which is rich in antibodies because it contains proteins for endurance and high amounts of germ killer so that exclusive breastfeeding can reduce the risk of death in babies and can prevent malnutrition and stunting in babies, at this time there are still mothers who do not give breast milk exclusively because the mother works outside the home so that the mother can not breastfeed her baby properly and regularly, knowledge and attitude is important in supporting the success of exclusive breastfeeding where if the mother's knowledge is good and the attitude is positive then the mother can give breast milk exclusively. The purpose of this study is to find out the knowledge and attitude of mothers towards exclusive breastfeeding. This study uses an descriptif research design, The population of this study is mothers who have babies aged 0-24 months at Puskesmas Simpang Kawat Jambi. Sample amounted to 42 respondents. This research instrument uses questionnaires and uses informed consent sheets. The results of this study showed that of the 42 respondents, most of the mothers had good knowledge, namely 29 people (69.0\%), while those who had enough knowledge as many as 13 people (31.0\%), and who had a positive attitude of 28 people (66.7\%) while those with negative knowledge as many as 14 people (33.3\%) conclusion of this study, mothers are well known and have a positive attitude towards exclusive breastfeeding.
\end{abstract}

Keywords: attitude, exclusive breast milk, knowledge

\begin{abstract}
Abstrak
Air susu ibu mengandung kolostrum yang kaya akan antibodi karena mengandung protein untuk daya tahan tubuh dan pembunuh kuman dalam jumlah tinggi sehingga pemberian ASI eksklusif dapat mengurangi risiko kematian pada bayi dan dapat mencegah terjadi gizi buruk danstunting pada bayi, pada saat ini masih ada ibu yang tidak memberikan air susu ibu secara eksklusif di karena ibu bekerja di luar rumah sehingga ibu tidak dapat menyusui bayinya dengan baik dan teratur, pengetahuan dan sikap merupakan hal yang penting dalam mendukung keberhasilan pemberian air susu ibu secara eksklusif dimana jika pengetahuan ibu baik serta sikap yang positif maka ibu dapat memberikan air susu ibu secara eksklusif. Tujuan penelitian ini untuk mengetahui pengetahuan dan sikap ibu terhadap pemberian ASI Eksklusif. Penelitian ini menggunakan desain penelitian deskriptif dengan pendekatan cross sectional, Populasi penelitian ini adalah ibu yang mempunyai bayi usia 0-24 bulan di Puskesmas Simpang Kawat Kota Jambi. Sampel berjumlah 42 responden. Instrument penelitian ini menggunakan kuesioner dan menngunakan lembar informed concent. Hasil dari penelitian ini menunujukan bahwa dari 42 responden sebagian besar ibu memiliki penegtahuan baik yaitu 29 orang $(69,0 \%)$, sedangkan yang memiliki pengetahuan cukup sebanyak 13 orang $(31,0 \%)$, dan yang memiliki sikap positif sebanyak 28 orang $(66,7 \%)$ sedangkan yang memiliki penegetahuan negatif sebanyak 14 orang (33,3\%) kesimpulan dari penelitian ini ibu berpengetahuan baik dan mempunyai sikap positif terhadap pemberian ASI Eksklusif
\end{abstract}

Kata Kunci : ASI eksklusif, pengetahuan, sikap

PENDAHULUAN

Dunia kembali merumuskan komitmen global dalam bidang kesehatan untuk 15 tahun ke depan. Kali ini diberi nama Sustainable Development Goals (SGDs) yang akan dicapai sampai dengan tahun 
2030. SDGs pembangunan berkelanjutan ini hadir menggantikan Millenium Development Goals (MDGs) yang disepakati oleh 198 negara di tahun 2000, yang bertujuan untuk mendorong kesejahteraan bagi seluruh orang di segala usia (Kemenkes RI, 2016)

Berdasarkan penelitian WHO, diseluruh dunia terdapat kematian bayi, khususnya neonatus, sebesar 10.000 .000 jiwa per tahun. Kematian bayi terjadi terutama di negara berkembang sebesar 99\%. Penyebab kematian bayi terkait dengan persalinan adalah BBLR (31\%), asfiksia (19\%), hipotermi (6\%), diare (4\%), infeksi (2\%), campak (1\%) dan lain-lain $(36 \%)$ dengan salah satu upaya yang dapat dilakukan untuk menurunkan angka kematian bayi adalah peningkatan pemberian Kolostrum, ASI esklusif, status gizi, deteksi dini, dan pemantauan tumbuh kembang (Dainty, 2017).

Hasil Survei Demografi dan Kesehatan Indonesia (SDKI) tahun 2017 menunjukkan angka kematian neonatus sebesar 15 per 1.000 kelahiran hidup, angka kematian bayi 24 per 1.000 kelahiran hidup, dan angka kematian balita 32 per 1.000 kelahiran hidup. Walaupun telah mengalami penurunan, tetap saja ini masih menjadi masalah yang harus di selesaikan secara keseluruhan. (SDKI, 2017). Persentase balita sangat pendek dan pendek usia 0-59 bulan di Indonesia tahun 2017 adalah 9,8\% sangat pendek dan 19,8\% pendek. Kondisi ini meningkat dari tahun sebelumnya yaitu persentase balita sangat pendek sebesar $8,57 \%$ dan balita pendek sebesar $18,97 \%$. Hal ini menjadi masalah di Indonesia karena menyebabkan pertumbuhan dan perkembangan anak menjadi terhambat (Kemenkes RI, 2017).

Berdasarkan data yang diperoleh dari Dinas Kesehatan Provinsi Jambi diketahui dari 12 Kabupaten prevelansi gizi kurang dan gizi buruk berdasarkan indikator $\mathrm{BB} / \mathrm{U}$ adalah $17.2 \%$ dan berdasarkan indikator $\mathrm{TB} / \mathrm{U}$ adalah $20.2 \%$. Persentase balita sangat pendek dan pendek umur 0-59 bulan menurut kabupaten atau kota tahun 2017 tertinggi yaitu, (34.1\%), dan terendah yaitu $(20,1 \%)$ (Dinkes Provinsi Jambi, 2019). Upaya pencegahan dan penanganan masalah gizi dan stunting salah satunya pemberian ASI eksklusif selama 6 bulan tanpa tambahan makanan apapun, pemberian kapsul vitamin A pada balita 659 bulan, pemberian tablet tambah darah (TTD) pada ibu hamil dan remaja putri, pemberian makanan tambahan pada ibu hamil KEK dan balita kurus, dan kecukupan energi dan zat gizi balita (Profil Kesehatan Indonesia, 2017).

Air susu ibu mengandung kolostrum yang kaya akan antibodi karena mengandung protein untuk daya tahan tubuh dan pembunuh kuman dalam jumlah tinggi sehingga pemberian ASI eksklusif dapat mengurangi risiko kematian pada bayi. Kolostrum berwarna kekuningan dihasilkan pada hari pertama sampai hari ketiga setelah persalinan (Rankin, 2010). Dalam keluarga ibu dan anak merupakan kelompok yang rentan, hal ini terkait dengan masa kehamilan ibu, masa persalinan, masa nifas pada ibu dan masa pertumbuhan dan perkembanghan pada anak. Hal ini juga yang menjadi alasan mengapa pentingnya upaya kesehatan ibu dan anak menjadi salah satu perioritas dalam proses pembangunan kesehatan di Indonesia dan di dunia (Profil Kesehatan Indonesia 2017).

Beberapa faktor yang menyebabkan bayi tidak diberikan ASI dengan baik. Faktor tersebut adalah faktor karakteristik ibu, faktor bayi, lingkungan, dukungan keluarga, pendidikan kesehatan, sosial ekonomi dan budaya (Budiharjo, 2013). Di daerah perkotaan dimana relatif lebih ibu yang bekerja untuk mencari nafkah mengakibatkan ibu tidak dapat menyusui bayinya dengan baik dan teratur. pengetahuan ibu merupakan faktor yang penting untuk mendukung keberhasilan ASI eksklusif pada bayi, karena semakin tinggi 
tingkat pendidikan seseorang semakin mudah menerima informasi sehingga semakin banyak pengetahuan yang dimiliki. Sebaliknya pendidikan yang kurang akan menghambat perkembangan sikap seseorang terhadap nilai nilai yang diperkenalkan (Fikawati, 2012). Sikap adalah respons tertutup seseorang terhadap stimulasi atau objek tertentu, yang sudah melibatkan faktor pendapat dan emosi ibu dalam mengambil keputusan untuk menyusui atau memilih susu botol. Tujuan penelitian ini untuk mengetahui deskripsi Pengetahuan dan Sikap Ibu tentang Pemberian ASI Eksklusif

\section{METODE PENELITIAN}

Penelitian ini merupakan penelitian deskriptif dengan pendekatan cros sectional yang bertujuan untuk mengetahui gambaran pengetahuan dan sikap ibu terhadap pemberian ASI eksklusif di wilayah kerja Puskesmas Simpang Kawat Kota Jambi. Populasi penelitian ini adalah seluruh ibu -ibu yang mempunyai bayi 024 bulan berjumlah 111 orang. Sampel pada penelitian ini berjumlah 42 responden dengan kriteria inklusi ibu bisa di ajak berkomunikasi, ibu yang bersedia menjadi responden untuk mengukur penegetahuan dan sikap yaitu mengunakan kuesioner yang terdiri dari 22 pertanyaan mengenai pengetahuan dan 15 penyataan mengenai sikap positif dan negatif yang terdiri dari pengertian ASI, manfaat ASI, jenis dan komposisi ASI, cara menyusui yang benar dan waktu pemeberian ASI. Hasil dari pengisian kuesioner kemudian di lakukan pengolahan data yang meliputi pengecekan data, pemberian kode, pemberian nilai dan memasukan data ke komputer untuk di analisis. Klasifikasi untuk variable pengetahuan di katakan baik jika jawaban $>75 \%$, cukup $56 \%-75 \%$ dan kurang $<56 \%$ sedangkan untuk sikap positif jika jumlah jawaban lebih dari mean $(41,14)$ dan negatif jika jumlah jawaban kurang dari mean $(41,14)$. Instrumen penelitian mengunakan lembar kuesioner dengan menjaga kerahasiaan responden.

\section{HASIL DAN PEMBAHASAN \\ Karakteristik responden}

Karakteristik umum responden menjadi penting agar memeproleh gambaran yang jelas mnegenai karakteritsik responden pada hasil penelitian. Data yang di tampilkan dalam karakteristik responden adalah data terdiri dari umur, pendidikan, pekerjaan dan paritas Distribusi karakteristik responden terlihat pada tabel berikut:

Tabel.1. Karakteristik responden

\begin{tabular}{lll}
\multicolumn{1}{c}{ Karakteritik } & \multicolumn{1}{c}{ F } & \multicolumn{1}{c}{$\%$} \\
\hline Umur & & \\
<20 Tahun & 4 & 4 \\
20-35 Tahun & 33 & 78,6 \\
$>$ 35 Tahun & 5 & 11,9 \\
\hline Jumlah & 42 & 100 \\
\hline Pendidikan & & \\
SD & 5 & 11.9 \\
SMP & 10 & 23.8 \\
SMA/SMK & 21 & 50 \\
Perguruan Tinggi & 6 & 14.2 \\
\hline Jumlah & 42 & 100 \\
\hline Pekerjaan & & \\
IRT & 30 & 71.4 \\
Karyawan Swasta & 6 & 14.2 \\
PNS & 6 & 14.2 \\
\hline Jumlah & 42 & 100 \\
\hline Paritas & & \\
Primipara & 28 & 66.7 \\
Multipara & 14 & 33.3 \\
\hline Jumlah & 42 & 100
\end{tabular}

Berdasarkan tabel 1 di proleh gambaran karakteristik responden bahwa dari 42 responden sebagian besar umur ibu 20-35 tahun berjumlah 33 responden $(78,6 \%)$, Pendidikan ibu SMA sebesar 21 responden (50\%). Pekerjaan ibu, ibu rumah tangga 30 responden $(71,4 \%)$ dan paritas ibu dengan primipara sebanyak 28 responden $(66.7 \%)$. 


\section{Pengetahuan tentang pemberian ASI Eksklusif}

Pada penelitian ini di gambarkan pengetahuan tentang ASI Eksklusif yang meliputi pengertian ASI, manfaat ASI, jenis dan koposisi ASI, faktor yang mempengaruhi ASI, cara menyusui yang benar dan waktu pemebrian ASI. Berikut hasilnya dapat di lihat pada tabel :

Tabel 2. pengetahuan ibu tentang pemberian ASI Eksklusif

\begin{tabular}{lcc}
\hline \multicolumn{1}{c}{ Pengetahuan } & F & \% \\
\hline Cukup & 13 & 31,0 \\
Baik & 29 & 69,0 \\
\hline \multicolumn{1}{c}{ Jumlah } & 42 & 100 \\
\hline
\end{tabular}

Berdasarkan tabel 2 di proleh dari 42 rsponden sebagian besar ibu memiliki pengetahuan baik yaitu 29 responden $(69,0 \%)$ dan yang mempunyai pengetahuan cukup sebanyak 13 responden $(31,0 \%)$.

\section{Sikap tentang pemberian ASI Eksklusif}

Pada peneltian ini di gambarkan sikap tentang ASI Eksklusif yang meliputi pengertian ASI, manfaat ASI, jenis dan koposisi ASI, cara menyusui yang benar dan waktu pemebrian ASI, hal yang perlu mempengaruhi ASI.

Tabel 3. Distribusi sikap ibu tentang pemberian ASI Eksklusif

\begin{tabular}{llc}
\multicolumn{1}{c}{ Sikap } & F & \% \\
\hline Negatif & 14 & 33,3 \\
Positif & 28 & 66,7 \\
\hline \multicolumn{1}{c}{ Jumlah } & 42 & 100
\end{tabular}

Berdasarkan tabel 3 di proleh dari 42 rsponden sebagian besar ibu memiliki sikap positif yaitu 28 responden $(66,7 \%)$ sedangkan yang mempunyai sikap negatif 14 responden $(33,3 \%)$.

Hasil penelitian yang telah dilakukan, berdasarkan karakteristik responden sebagian besar ibu berada pada rentang usia 20-35 tahun yaitu sebanyak 33responden (78.6\%). Hal ini menunjukan bahwa ibu berada dalam rentang usia reproduksi sehat dimana wanita sudah mencapai tingkat kematangan mental sehingga dapat menjalani proses reproduksi dengan baik. Terkait dengan pendidikan sebagian besar ibu berpendidikan SMA yaitu sebanyak 21 responden $(50 \%)$, pendidikan merupakan salah satu unsur penting dalam menentukan keberhasilan dalam pemberian ASI eksklusif pendidikan berpengaruh pada aspek kehidupan seperti pikiran, perasaan dan sikap karena semakin tinggi pendidikan seseorang maka semakin tinggi pula kemampuan dasar yang dimiliki seseorang khususnya pada pemberian ASI eksklusif. Tingkat pendidikan dapat mempengaruhi sikap ibu dalam menyerap informasi tentang pentingnya ASI eksklusif untuk bayi. Terkait dengan pekerjaan ibu presentase yang tertinggi adalah Ibu Rumah Tangga (IRT) yaitu sebanyak 30 responden (71.4\%), pekerjaan merupakan salah satu alasan tidak memberikan ASI Eksklusif karena waktu dirumah lebih sedikit dibandingkan dengan ibu yang tidak bekerja, sehingga waktu untuk bersama bayi juga semakin sedikit. semakin banyak ibu bekerja sehari penuh dapat menyebabkan penurunan pemeberian ASI eksklusif, Sebenarnya ibu pekerja juga bisa memberikan ASI Ekskluisf pada bayinya yaitu dengan cara memompa atau memerah ASI kemudian di simpan di prizer dan di berikan nanti pada saat bayi ingin menyusu. Berdasarkan riwayat kehamilan sebagian besar ibu dengan primigravida sebanyak 28 responden $(66,7 \%)$. Hal ini menunjukkan bahwa responden sebelumya belum mempunyai pengalaman.

Berdasarkan hasil penelitian yang diperoleh melalui pengisian kuesioner pengetahuan bahwa dari 42 responden, yang berpengetahuan baik sebanyak 29 responden $(69,0 \%)$. Pengetahuan adalah merupakan hasil "tahu" dan ini terjadi setelah orang mengadakan pengindraan terhadap suatu objek tertentu. Penginderaan terhadap objek terjadi melalui panca indra manusia yakni penglihatan, pendengaran, 
penciuman, rasa dan raba dengan sendiri. Pengetahuan umumnya datang dari pengalaman dan informasi yang di dapat melalui guru, teman, keluarga, suart kabar dll. Pengetahuan ibu tentang ASI esklusif kurang maka dapat mempengaruhi prilaku/sikap ibu dalam pemberian ASI eksklusif Perilaku menyusui yang kurang mendukung diantaranya membuang kolostrum karena dianggap tidak bersih dan kotor,pemberian makanan/ minuman sebelum ASI keluar (prelaktal), serta kurangnya rasa percaya diri informan bahwa ASI tidak cukup untuk bayinya.

Hasil penelitian ini sejalan dengan penlitian yang diakukan oleh Annisa Tiara Hayati (2019) yang berjudul "Gambaran pengetahuan ibu tentang ASI ekslusif di dusun Beji Kerajan Puskesmas Leyangan" berdasarkan pengetahuan ibu menyusui tentang ASI eksklusif sebagian responden mempunyai pengetahuan baik, sebanyak 12 responden $(50,0 \%)$ dari 24 responden. Dan juga sejalan dengan penelitian parah febrianti yang berjudul" gambaran pengetahuan dan sikap ibu postpartum tentang pemberian ASI Eksklusif di puskesmas Bogor tahun 2018" berdasarkan pengetahuan responden mengenai pemberian ASI Eksklusif sebagian besar ibu perpengetahuan baik sebanyak 29 responden $(88 \%)$ dari 33 responden.

Sedangkan hasil pengisian pernyataan sikap didapatkan 28responden $(66,7 \%)$ bersikap positif terhadap pemberian ASI Eksklusif pada bayi. Menurut Soekidjo Notoatmodjo (2010) komponen yang mempengaruhi sikap adalah kepercayaan atau keyakinan, keadaan emosional, dan kecenderungan untuk bertindak. Pada penelitian ini dapat dikatakan bahwa yang menyebabkan ibu hamil bersikap positif dalam pemberian ASI Eksklusif dikarenakan adanya keyakinan ibu terhadap pemberian ASI Eksklusif yang bermanfaat bagi bayinya dan kondisi emosional ibu yang dalam keadaan baik sehingga mempengaruhi ibu dalam melakukan suatu tindakan positif terhadap pemberian ASI Eksklusif.

Hasil penelitian ini sejalan dengan penelitian yang di lakukan oleh sarah febrianti yang berjudul "Gambaran Pengetahuan Dan Sikap Ibu Postpartum Tentang Pemberian ASI Eksklusif Di Puskesmas Bogor Tahun 2018" dengan hasil sikap responden tentang pemberian ASI Eksklusif di puskesmas bogor lebih dari setengah responden mempunyai sikap positif sebanyak 17 responden (52\%) dari 33 responden.

Dukungan yang sangat diperlukan ibuagar bersikap positif tentang pemberian ASI Eksklusif yaitu adanya dukungan keluarga, moivasi dari orang-orang terdekat ibu, suami, teman dan petugas kesehatan dengan memberikan konseling dan penyuluhan, sehingga ibu termotivasi dan meningkatkan kepercayaan atau keyakinan ibu bahwa pemberian ASI Ekskluisf sangat penting dan sangat baik untuk ibu terutama bagi bayi untuk meningkatkan imunitas atau daya tahan tubuh bayi, meningkatkan pertumbuhan dan perkembangan tubuh dan psikologis bayi, mencegah terjadinya infeksi penyakit, dan untuk mencegah terjadinya stunting yaitu suatu kejadian pendek dan sangat pendek yang terus menjadi masalah kesehatan di dunia dan di Indonesia, kejadian ini disebabkan oleh kurangnya gizi pada bayi yang seharusnya terpenuhi dengan pemberian ASI Eksklusif karena ASI mengandung zat gizi yang dibutuhkan bayi dan zat gizi tersebut tidak terdapat pada susu formula,hal ini yang menyebabkan pertumbuhan dan perkembangan anak menjadi terhambat.

\section{SIMPULAN}

Pengetahuan dan sikap ibu di wilayah kerja puskesmas simapang kawat mayoritas berpengetahuan baik dan mempunyai sikap positif terhadap pemberian ASI Eksklusif 


\section{SARAN}

Disarankan kepada petugas Puskesmas agar dapat meningkatkan konseling pada ibu -ibu yang mempunyai bayi mengenai ASI Eksklusif dan mengadakan penyuluhan secara rutin saat kegiatan Posyandu sehingga dapat menambahkan/meningkatkan pengetahuan ibu tentang pemberian ASI Eksklusif.

\section{UCAPAN TERIMAKASIH}

Penulis mengucapkan terimakasih kepada Sekolah Tinggi Ilmu Kesehatan Baiturrahim atas dana dan fasilitas serta surat izin penelitian ini dan kepala puskesmas dan bidan yang telah memberikan izin dan membantu dalam melakukan penelitian ini sehingga peneltian ini berjalan dengan lancar.

\section{DAFTAR PUSTAKA}

Anisa. Hubungan Tingkat Pengetahuan Dan Pendidikan Ibu Terhadap Pemberian ASI pada Bayi Baru Lahir Di RSIA Siti Fatimah Makassar. Jurnal Ilmiah Kesehatan 2012

Asih, Y, Kent.Buku Ajar Asuhan Kebidanan Nifas dan Menyusui. Jakarta Timur.2016.

Cadwell, K. Buku Saku Manajemen Laktasi.Jakarta.2011

Dainty, Astuti, S, Mandiri Ariyati.Asuhan Kebidanan Pada Ibu Bersalin. Jakarta.2017

Febrianti S, Agustina. Gambaran pengetahuan dan sikap ibu postpartum tentang pemberian ASI Eksklusif di Puskesmas bogor. poltekes kemenkes bandung.2018.

Fore Henrietta, Lembaga UNICEF. Tingkat Kematian Bayi di Inggris.2018.

Hayati. T.H. Gambaran pengetahuan ibu tentang ASI ekslusif di dusun Beji KerajanPuskesmasLeyangan.2019.

Hendrik, Y, Yuliana..Buku Saku MaternalNeonatal (Maternal-Neonatal Facts Made Incredibly Quick). Jakarta2016
Hidayat. Metode Penelitian Kesehatan Paradigma Kuantitatif. Jakarta . 2010.

Jannah, Yanti. Jurnal Pemberian ASI Eksklusif.Bandung2011.

Kementerian Kesehatan. Indonesia. 2018

Khairuniyah, Manajemen laktasi. Jakarta.2016.

Kusuma, A. Jurnal Kehamilan dan pemberian ASI Eksklusif pada bayi baru lahir. Pontianak 2016.

Notoadmodjo, S. Metodologi Penelitian Kesehatan. Rineka Cipta. Jakarta2010.

Notoadmodjo. IlmuPerilaku Kesehatan. PT Rineka Cipta. Jakarta.2010.

Nursalam. Konsep dan penerapan metodologi penelitian ilmu keperawatan. Surabaya Salemba Medika.2015

Pollard, M. Asuhan Berbasis Bukti. Jakarta.2016.

Purwanto. Instrummen penelitian sosial dan pendidikan. Yogyakarta. Pustaka Pelajar. 2011

Prawirohardjo. Asuhan Kebidanan Pada Masa Nifas. Jakarta.2010.

Profil Kesehatan Indonesia.2017.

Profil Kesehatan Provinsi Jambi. 2019.

Pusat Data dan Informasi Kementerian Kesehatan RI. 2018.

Rankin, Stables. Asuhan Bayi Baru Lahir dan Pemberian ASI Eksklusif. Jakarta.2010.

Riset Kesehatan DasarIndonesia. 2018.

Survei Demografi dan Kesehatan Indonesia (SDKI).Angka Kematian Bayi (AKB).2017.

Williamson, A. Buku Ajar Asuhan Neonatus. Jakarta.2014.

World Health Organizatoin (WHO). 2018. 